\section{Regulation, Market Structure, and the Bank Failures of the Great Depression}

\section{David C. Wheelock}

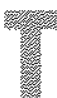
he surge of bank failures in the United States during the 1980s focused the attention of policymakers and researchers on the causes of failure, especially on the role of government policy. Deposit insurance had left the banking industry more leveraged than it would otherwise have been, and encouraged individual banks to take greater risks as losses eroded their net worth. In response, tegulators imposed risk-adjusted capital requirements and Congress enacted the Federal Deposit Insurance Corporation Improvement Act of 1991 (FDICIA), which mandated risk-based deposit insurance premiums and refined the risk-based capital standards. Similarly, the enactment of The Interstate Banking and Branching Efficiency Act of 1994, which permitted interstate branching, stemmed from the view that branching restrictions hamper geographic diversification and had contributed to the high number of failures in regions suffering economic downtums.

The United States last experienced high numbers of bank failures during the Great Depression, when some 9,000 banks failed. Researchers have blamed various government policies, especially branching restrictions, for contributing to banking instability during the Depression. There has, however, been little empirical study of the effects of banking market structure and regulation on failures during this period, a gap which this article attempts to fill.

Previous studies have taken little notice of the wide interstate variation in the number of failures and failure rates during the Great Depression. This article investigates whether this variation can be explained solely by differences in the extent to which income declined, or whether various state banking policies or differences in market structure contributed to interstate variation in failure rates. It also investigates why banking market structures differed across states. The analysis indicates that, after controlling for the extent to which economic activity declined, the proportion of deposits in failed banks was lower in states where branch banking was more prevalent. In addition, both the bank failure rate and proportion of deposits in failed batiks varied inversely wit the relative number of federally chartered (national) banks in a state. Finally, the study shows that the state deposit insurance systems of the 1920 s had lingering effects on banking market structures even after insurance had ended. Thus, as researchers have found for the 1980s, government policies, such as branching restrictions and deposit insurance, appear to have had measurable impacts on market outcomes and bank failures during the Great Depression.

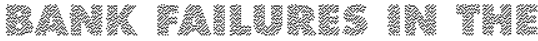

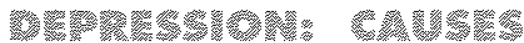

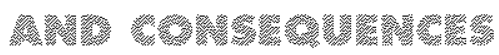

From 1929 to 1933 , U.S. gross national product declined 29 percent (in constant dollars), the price level fell 25 percent, the unemployment rate reached 25 percent, and some 9,000 banks suspended operations because of financial distress. A bank that suspended operations need not have "failed," in that a receiver need not have been appointed to liquidate the bank. Suspended banks, however, include only those that closed on
1 FOCLA also limited the discretion of regulatoss to permiti insolvent baiks from continuing to operote. Some reseatchess angue flat the dasuete poliky known os "toobiytofoll" had encournged excessive risk faking bercuse it had the effect of expant ing deposit insurance caverage beyond $\$ 100,000$ per occount of butiks thet teguledors deeried too lagge to dose. See Keeloy (1990) for futher andirysis of the vole of deposit insurance dering the $1980 \mathrm{~s}$. 
account of financial difficulty. Following much of the literature, I use the terms "suspension" and "failure" interchangeably.

Economists have debated the causes of the Depression since the 1930s. In the past 30 years, this debate has focused on the role of bank failures. In Monetary History of the United States, Friedman and Schwartz (1963) argue that banking panics in the autumn of 1930 , and the spring and autumn of 1931 sharply reduced the supply of money, which, in turn, caused economic activity to decline. Other researchers, however, such as Temin (1976), contend that bank failures occurred largely as a result of falling national income. In Temin's view, the economic downturn reduced the demand for money, and bank failures were the means by which the money supply fell to accommodate that decline.

The debate over the role of bank failures and monetary forces in causing the Great Depression continues to simmer, and is reviewed by Wheelock (1992b). A recent view, originating with Bernanke (1983), proposes a non-monetary explanation of how bank failures contributed to the Depression. Bernanke argues that apart from their impact on the money supply, bank failures depressed output by raising the cost of credit intermediation.

Much of the research on the causes and consequences of bank failures during the Depression has had a macroeconomic orientation, with little emphasis on the role of reg. ulation or market structure. Some researchers, however, have argued that the prevalence of unit banking left the U.S. banking system especially vulnerable to failures during the Depression, and that nationwide branching helped limit failures and banking panics in other countries. For example, the conventional view is that nationwide branching protected the Canadian banking system during the Depression (for example, see White, 1984; or Grossman, 1994), though Kryznowski and Roberts (1993) estimate that on a market value basis, all Canadian banks were insolvent at some point during the Depression. This focus on branching vs. unit banking has been national, with little consideration of whether differences in state branching laws, other banking regu- lations or market structure contributed to interstate differences in bank failure rates. Regional variation in failures has largely been ignored or simply attributed to differences in the extent to which income declined.

Several studies have attempted to determine whether the causes of bank failures during the Depression were like those of failures during the 1920s. For example, Temin (1976) finds that, like the 1920s, declining agricultural income explains many of the failures of 1930 and 1931. White (1984) shows that the characteristics of banks that failed in 1930 were like those of previous failures. Calomiris and Mason (1994) present similar findings for failures during the Chicago banking panic of June 1932. On the other hand, Wicker (1980) shows that many failures in 1930 stemmed from the collapse of one Southern financial institution, Caldwell and Company, which he concludes was largely independent of the decline in economic activity. Stauffer (1981) offers further evidence that bank failures were independent of the decline in activity by showing that in the 11 cotton-producing states with significant declines in output, bank failures were more closely related to banking market structure than to changes in local income. Whether this was also true of other states, however, is unclear.

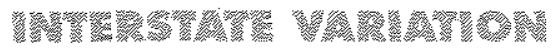

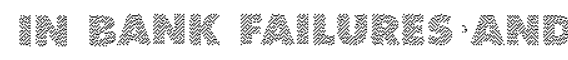

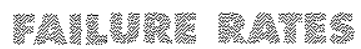

This article investigates the interstate variation in bank failures during 1929-32. The failures of 1933 are not studied here becatuse the bank holiday in March 1933, and subsequent institutional changes, substantially altered the timing and likely causes of failures. All banks were shut during the bank holiday, and only those licensed by regulators were permitted to reopen. Not all banks that would reopen had done so by the end of 1933, and some that did were later found to be insolvent. This suggests that the determinants of bank failures in 1933 should be studied apart from those of other Depression years. Similarly, I leave for future research the causes of failures during the remainder of the 1930 s. 
Figure 1 shows the distribution of bank failutes actoss the United States during 1929-32 (see the appendix for data sources). Rhode Island escaped the period without any bank failures. No other state had fewer than two failures. Other states with fewer than 10 bank failures include Vermont, Maine, New Hampshire, Delaware, New Mexico and Wyoming. Generally, Midwestern states suffered the highest numbers of bank failures. Illinois had 602 failures, the most of any state. Only three other states had more than 300 failures: Iowa with 476, Nebraska with 358 and Missouri with 328 . The mean number of failures across all states was 120 , and the median was 91 failures. For comparison, from 1980 to 1989 , the two states with the most bank failures were Texas with 350 and Oklahoma with 105.

The number of failures can, of course, be a misleading statistic because the number of banks varies widely across states. Figure 2 maps the distribution of bank failure rates during 1929-32, in which the annual failure rate is defined as the total number of suspensions during a year divided by the number of banks operating at mid-year. Even though Illinois had the most failures, it did not have the highest failure rate. That dubious distinction went to Nevada, which had a yearly average failure rate of more than 16 percent, despite having just 19 bank failures during the period. Illinois, other Midwestern and Southern states with high numbers of bank failures, however, generally also had high failure rates. Besides Nevada, other states with high failure rates included South Carolina, Florida and Arkansas, each with a rate of 15 percent. At the other extreme, five New England states, plus New Mexico, Wyoming, New York, Massachusetts and New Jersey, all had failure tates under 3 percent. The mean failure rate among all states was 6.6 percent, while the median was 5.5 percent. For comparison, between 1980 and 1989 , the average annual bank failure rate in the United States was 0.77 percent. Eight states had no failures during the period, while Alaska, Oregon and Texas had failure rates of 6.3 percent, 2.4 percent and 2.3 percent, respectively, the most of any states.

Figure 3 maps the average annual rate of deposits in failed banks during 1929-32, where

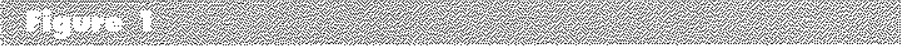

\section{Number of Bank Suspensions, 1929-32}

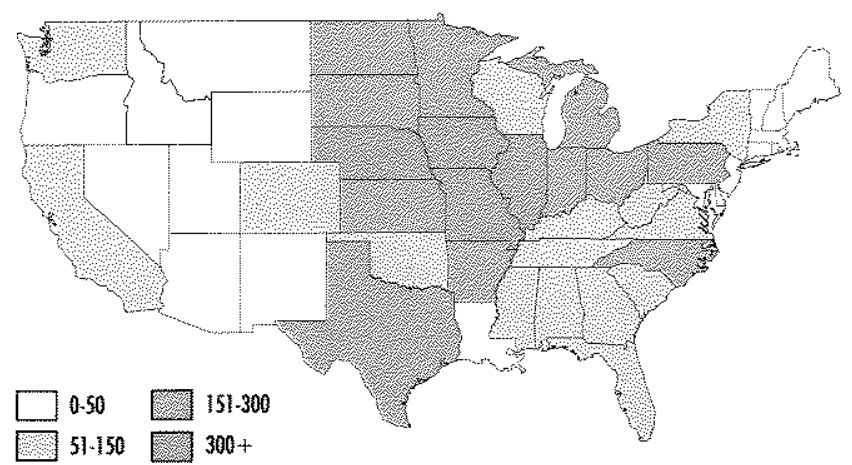

\section{a.}

\section{Bank Suspensions Per Aetive Bank, 1929-32}

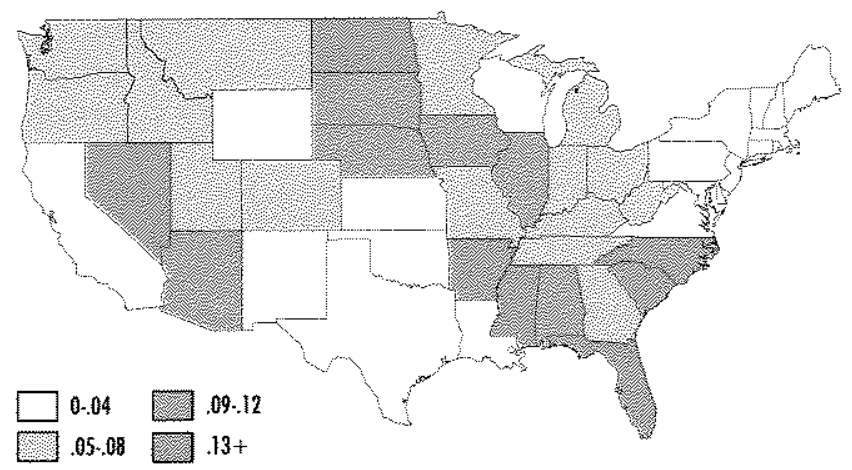

the annual rate of deposits in failed banks is the sum of deposits in failed banks during a year divided by the volume of deposits in all banks at mid-year. A state could have had a low number of bank failures, or a low failure rate, but a high rate of deposits in failed banks if those banks that did fail held a high share of the state's bank deposits. On the other hand, a high number of failures, or a high failure rate, did not necessarily produce a high rate of deposits in failed banks if failing banks held a comparatively low share of a state's deposits. Moreover, there is no reason to expect that the determinants of the bank failure rate and rate of deposits in failed banks will be the same.

During 1929-32, the rate of deposits in failed banks and the bank failure rate were highly correlated (a correlation coefficient 
(1)

\section{Deposits in Suspended Benks Per Bollar of Deposits in Active Banks, 1929-32}

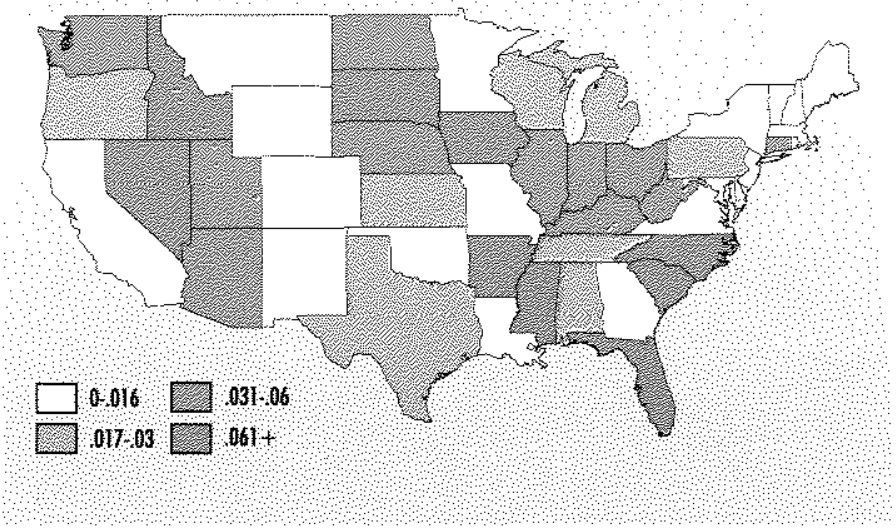

of 0.85 ) and Nevada again had the highest rate of deposits in failed banks at 16 percent. Still, comparison of Figures 2 and 3 reveals that not all states with high bank failure rates also had high rates of deposits in failed banks, and that some states with relatively low failure rates had high rates of deposits in failed banks. Connecticut, for example, had a relatively low bank failure rate ( 3.6 percent), but a relatively high rate of deposits in failed banks ( 3.9 percent). On the other hand, Georgia had a high failure rate ( 8.0 percent), but a comparatively low rate of deposits in failed banks (1.6 percent) because most of the banks that failed in Georgia were quite small. Besides Nevada, other states with high rates of deposits in failed banks included South Carolina, Florida, North Carolina, lowa, Mississippi and Arkansas, all with rates above 7 percent. States with low rates of deposits in falled banks include those in the Northeast, California and scattered others. The mean rate across all states was 3.4 percent, while the median was 2.1 percent.

What explains interstate differences in bank failure rates and in the rate of deposits in failed banks? One hypothesis is that banking distress was more severe in regions suffering the largest declines in economic activity because banks in those regions likely experienced the largest losses on their loans and other assets. The extent to which per capita income fell during 1929-32 ranged from 32 percent in Massachusetts to 56 percent in Mississippi (both the mean and median declines were 44 percent). It seems reason- able to expect that failure rates were higher in states suffering the largest income declines.

Conceivably, income fell more in some states because of a high rate of bank failutes. Some researchers argue that banking panics triggered the decline in national income, while others contend that bank failures merely reflected falling income caused by other forces. Ideally, an econometric analysis of the determinants of bank failure would treat the change in income as simultaneously determined with bank failures. The specification of such a system in this context presents a number of challenges and is therefore left to future research. Among the difficulties is a lack of suitable variables to serve as instruments for state-level changes in per capita income. For example, state income estimates prior to 1929 are not available. Readers are cautioned that the models presented here may be subject to simultaneous-equations bias.

As in the 1920 s, the majority of banks that failed during the Depression were small rural banks whose prosperity depended largely on agriculture. Alston, Grove and Wheelock (1994) show that differences in farm foreclosure rates explain much of the interstate variation in bank failure rates during 1926-29. Other studies, including Friedman and Schwartz (1963) and Temin (1976), note a relationship between agricultural distress and bank failures in the 1930s, but do not examine whether falling agricultural income dominates other possible explanations of failures. An exception is Stauffer (1981), but he focuses exclusively on 11 Southern states. Moreover, even though falling agricultural income might explain a high number of bank failures during the Depression, because the rural banks that failed in such large numbers were typically quite small, agricultural distress might not explain the proportion of deposits in failed banks.

Apart from the severity of agricultural distress, the preponderance of failures among very small banks suggests that bank size itself, or some other characteristic of small banks, might explain their relatively high failure rate. The failure rate in 1930-31 of national and state-chartered banks was inversely correlated with bank size, declining from 25 percent of active banks on June 30, 1930, for banks with 
fewer than $\$ 150,000$ of loans and investments, to 2 percent for banks with at least $\$ 50$ million of loans and investments (Federal Reserve Board, non-dated publication, p. 67). If small banks were less diversified than large banks, either geographically or along product lines, they might have been more vulnerable to a downturn in a given market. For example, White (1986) argues that their greater involvement in the securities business might have left large banks better diversified and, hence, less likely to fail than small banks. Accordingly, a predominance of small, undiversified unit banks might explain the generally higher bank failure rates of the rural Midwest and South.

A lack of diversification might not explain entirely why the failure rate of small banks excecded that of large banks. Typically, small banks had state charters and the fallure rate of state-chartered banks during the Depression exceeded that of national banks. In 1929 , the failure rates of national and state banks were 0.8 and 3.4 percent, respectively; in 1930 , they were 2.2 and 7.1 percent; in $1931,6.0$ and 12.1 percent; and in 1932, 4.5 and 8.7 percent (Bremer, 1935, p. 46). Differences in regulation or supervision might explain the relatively high failure rate of state-chartered banks and, hence, of small banks. For example, in most states, national banks had higher minimum capital requirements and were subject to greater restrictions on real estate lending than state-chartered institutions.

Apart from differences in the regulation or supervision of national and state banks, other state banking policies might have affected state banking markets or failure rates. Branch banking restrictions, for example, can hamper diversification and, to the extent that the fiming or magnitude of a decline in economic activity varies geographically, a bank with multiple offices might be able to offset losses in one region with profits in another. Although unit banking predominated in the United States in the 1930 s, several states permitted at least limited branching within their borders. In 1930, nine states, including Arizona, California and North Carolina, permitted state-wide branching, and 12 others permitted limited branching. Banks in 18 states had no branches at all. As of June 1930, U.S. commercial banks operated 3,618 branches. Of these, 853 were in California, with some 300 belonging to the Bank of Italy (the forerunner of Bank of America). California had nearly twice as many branch offices as it had banks. Rhode Island was the only other state having more branches than banks.? If the opportunity to branch afforded banks greater diversification, or permitted them to operate at a more efficient scale, states that allowed branching might have had lower bank failure rates.

A second policy that could have affected bank failure rates is deposit insurance. Eight states - Kansas, Mississippi, Nebraska, North Dakota, Oklahoma, South Dakota, Texas and Washington - enacted insurance systems for their state-chartered banks following the "Panic of 1907." In each system, insurance premiums were low and unrelated to failure risk, thereby creating a subsidy that appears to have caused more bank entry and greater nisk-taking than would have otherwise occurred (see Calomiris, 1989, 1992; and Wheelock, 1992a, 1993).

Banks proliferated throughout the United States in the two decades before 1920 . In 1900 , the United States had 12,427 banks. By 1920 , the number had reached 30,291 , thanks in part to rapid growth in agricultural states during the commodity price boom of World War I (Board of Governors, 1959). The number of banks increased particularly fast in states with deposit insurance systems, such as North Dakota, which by 1920 had one bank for every 720 persons, the most of any state.

The wartime boom came to an end in 1920. Commodity prices collapsed, triggering widespread bank failures in rural areas. Subsequently, states with the highest numbers of banks per capita in 1920 suffered the highest failure rates, and members of state insurance systems had higher falure rates than uninsured banks. By 1929 , each of the state insurance systems was either insolvent or closed by state authorities. Because none of the systems carried a state guaranty, depositors, rather than taxpayers, suffered losses if insurance premiums were inadequate. An exception was Mississippi, where the state assumed the obligations of its insurance system and issued bonds to reimburse depositors of failed banks. Further detail about the state insurance systems can

\footnotetext{
${ }^{2}$ Aggreggote dato on brond benking are from the Federal Reserve Boord (December, 1930, p. 812). The doto for the Bank of lotoly are frota Tippetts $(1929,0.335)$ and are for 1927 .
${ }^{3}$ Although not consmon of the fime, mulitiplebunk holding componies also colla have provided some geo- gonplite diversification. This artide, hawever, does noi investignote whether hodding companies oftect. ed state Falure rates.


be found in Federal Deposit Insurance Corporation (1956) or Caloniris (1989).

Although states with deposit insurance systems had high numbers of bank failures during the 1920 s, they still had significantly more banks per capita in 1929 than other states. Generally, the more banks per capita a state had in 1929, the higher its bank failure rate during 1929-32. (The correlation coeffcient is 0.33 , which is significant at the 0.05 leve1). Thus, by affecting the number of banks per capita or other aspects of market structure, or if banks that had been members of state deposit insurance systems continued to hold riskier portfolios, deposit insurance could have contributed to bank failures during the Great Depression.

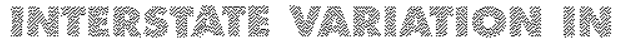

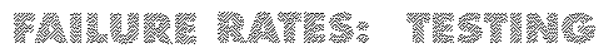

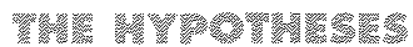

The main objective of this article is to discern whether differences in state banking policies contributed to interstate variation in failure rates during the Great Depression. Accordingly, in modeling the determinants of bank failure rates during 1929-32, 1 control for cross-state differences in the level of economic distress by including the percentage change in per capita income, and the average annual farm and business failure rates as independent variables. I expect that the more per capita income fell and the higher the rates of farm and business failures, the higher were state bank failure rates and rates of deposits in failed banks.

To test whether within-state branching helped to limit failures, perhaps by enabling greater diversification or scale, I include the ratio of branches to operating banks in 1930 as another independent variable. 1 expect that failure rates and the rate of deposits in failed banks were lower where branching was more prevalent.

Next, $I$ include dummy variables reflecting whether a state had a deposit insurance system during the $1920 \mathrm{~s}$. By affecting a state's banking market structure, deposit insurance could have had an impact on failure rates during the 1930 s even though insurance no longer existed. Deposit insurance caused more entry and encouraged greater risk-taking than would have otherwise occurred and, hence, the banking systems of states with insurance might have been more vulnerable to a decline in econonic activity. In other words, failure rates might have been higher because deposit insurance generated more banks than were economically viable once insurance had ended, or because banks that had been insured continued to hold especially risky portfolios.

Apart from its impact on the number of banks per capita, the collapse of state deposit insurance systems in the 1920 s caused declines in the number of state-chartered banks relative to the number of national banks. In 1908 , the Comptroller of the Currency ruled that national banks could not join state deposit insurance systems. This led to a relative increase in the number and deposit shares of state-chartered banks in the states enacting insurance systems. The decade-long shakeout of rural banks that followed the collapse of commodity prices in 1920 reduced the number of state banks. More than 5,700 banks failed in the '20s, and Alston, Grove and Wheelock (1994) show that rural failure rates were higher in states with deposit insurance systems, after controlling for the extent of agricultural distress. Moreover, Wheelock (1993) finds that the demise of deposit insurance caused especially large declines in the relative number of state-chartered banks, both because the rate of failure among insured state banks was high and because many state banks switched to national charters to escape state insurance systems. These effects were especially large in states where the insurance systems collapsed (or were closed by state authorities) early in the decade. For this reason, the impact of deposit insurance on market structure, and hence on failures during the 1930s, might differ in states where insurance ended early in the 20 s from its impact in other insurance states. Therefore, I include one dummy variable, set equal to 1 in states in which insurance lasted to either 1928 or 1929 (Mississippi, North Dakota and Nebraska), and to zero otherwise. I set a second dummy equal to 1 in states in which insurance ended by the mid-1920s (Kansas, Oklahoma, South Dakota and Texas), and to 


\begin{tabular}{|c|c|c|c|c|c|c|c|c|}
\hline \multicolumn{9}{|c|}{$\begin{array}{l}\text { Determinants of Inferstafe Variation in Bank Failure Rates } \\
\text { Dependent Variable: average failure rafe, 1929-32, models 1-4; } \\
\text { Dependent Variable: log of the ratio of deposits to failed banks, 1929-32, models 5-8 }\end{array}$} \\
\hline & (I) & (2) & (3) & (4) & (5) & (6) & (7) & (8) \\
\hline hinercept & $\begin{array}{l}-8.98 \\
(1.83) \%\end{array}$ & $\begin{array}{l}7.82 \\
(173)^{*}\end{array}$ & $\begin{array}{l}79.9 \% \\
(1.77)^{\circ}\end{array}$ & $\begin{array}{r}-571 \\
10.72)\end{array}$ & $\frac{-7.22}{(4.95)^{* * *}}$ & $\frac{6.54}{(4.14)^{+*}}$ & $\frac{6.38}{(4.35)^{* * *}}$ & $\begin{array}{l}347 \\
11.23)\end{array}$ \\
\hline$\triangle$ Per copita income & -23.57 & -26.93 & $24: 16$ & $\begin{array}{l}19.92 \\
(203)^{* *}\end{array}$ & $\frac{5.79}{(1.73)^{\circ}}$ & $\begin{array}{l}-4.40 \\
(1.18)\end{array}$ & $\begin{array}{l}-1.91 \\
10.53)\end{array}$ & $\begin{array}{l}1.66 \\
(0.50)\end{array}$ \\
\hline form fulure raie & $\begin{array}{l}0.21 \\
(3.28)^{* *}\end{array}$ & $\frac{0.16}{(2.63)^{* *}}$ & $\begin{array}{l}0.11 \\
.11 .67)\end{array}$ & $\begin{array}{l}0.16 \\
01.87 \%\end{array}$ & $\begin{array}{l}0.03 \\
(1.11)\end{array}$ & $\begin{array}{l}0.03 \\
(1.27)\end{array}$ & $\begin{array}{l}0.01 \\
(0.33)\end{array}$ & $\begin{array}{l}0.004 \\
(0: 16)\end{array}$ \\
\hline business foilure rote & $\begin{array}{r}-0.73 \\
(0.57)\end{array}$ & $\begin{array}{l}-0.15 \\
(0.11)\end{array}$ & $\begin{array}{l}0.03 \\
(0.03)\end{array}$ & $\begin{array}{l}-0.42 \\
(0.26)\end{array}$ & $\begin{array}{r}0.28 \\
(0.71)\end{array}$ & $\begin{array}{l}0.34 \\
(0.87)\end{array}$ & $\begin{array}{c}0.34 \\
{[0.95]}\end{array}$ & $\begin{array}{c}0.41 \\
\{1.09\}\end{array}$ \\
\hline Bronthing ratio & & $\begin{array}{r}-1.73 \\
(1.33)\end{array}$ & $\begin{array}{c}-1.33 \\
01.021\end{array}$ & & & $\frac{100}{(2.21)^{*}}$ & $\begin{array}{l}0.78 \\
(1.82)^{*}\end{array}$ & \\
\hline 01 (MS, ND, NE) & & $\begin{array}{c}2.30 \\
(1.35)\end{array}$ & $\begin{array}{c}2.31 \\
(1.37)\end{array}$ & & & $\begin{array}{l}0.16 \\
(0.24)\end{array}$ & $\begin{array}{l}0.13 \\
(0.21)\end{array}$ & \\
\hline 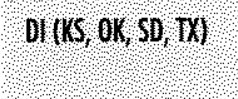 & & $\begin{array}{l}-3.61 \\
(2.85)^{\prime \cdots}\end{array}$ & $\begin{array}{l}-2.99 \\
(2.24)^{* *}\end{array}$ & & & $\begin{array}{r}-0.38 \\
(0.65)\end{array}$ & $\begin{array}{r}0.06 \\
(0.10)\end{array}$ & \\
\hline In Banks per copito & & & & $\begin{array}{l}-1.52 \\
(102)\end{array}$ & & & & $\begin{array}{c}-0.09 \\
(0.23)\end{array}$ \\
\hline In Notional bank ratio & & & $\begin{array}{c}-1.50 \\
(1.38)\end{array}$ & $\begin{array}{l}240 \\
(211)^{* *}\end{array}$ & & & $\begin{array}{l}-1.03 \\
(2.76)^{* * * *}\end{array}$ & $\begin{array}{l}1.00 \\
(2.73)^{+* *}\end{array}$ \\
\hline Ih Average bonk size & & & & $\begin{array}{r}-0.76 \\
(0.85)\end{array}$ & & & & -0.41 \\
\hline Adjusted $\mathrm{R}^{\text {? }}$ & .85 & 88 & 88 & 86 & 10 & 15 & 27 & 26 \\
\hline
\end{tabular}

Note: The coefficients of models 1-4 are nulfiplied by 100 ; absolute values of i-statistics ore in parentheses; *** ** and * indicate statistical significonce at the $.01,05$ and .10 levels. The adiusted $R^{2}$ is presented for use in compesing olternative specitications but, beceuse of the heteroscedasticity corredion, daes not indicale the proportien of the variotion in the dependeat variable explained by models $1-4$.

zero otherwise. The insurance systems of these states had all ceased to function by 1926 , though, in some cases, did not officially close until a later date. Although Washington had an insurance system, it collapsed after the failure of the first, and largest, insured bank in 1921. Because of its short life, I treat Washington as not having had insurance. Like other states where insurance ended early, however, many of Washington's state banks switched to federal charters.

If deposit insurance left states with more banks than were economically viable, or with banks having especially risky portfolios, the coefficients on one or both of these dummies should be positive in the failure rate regressions. On the other hand, if insurance caused the relative number of banks with federal 


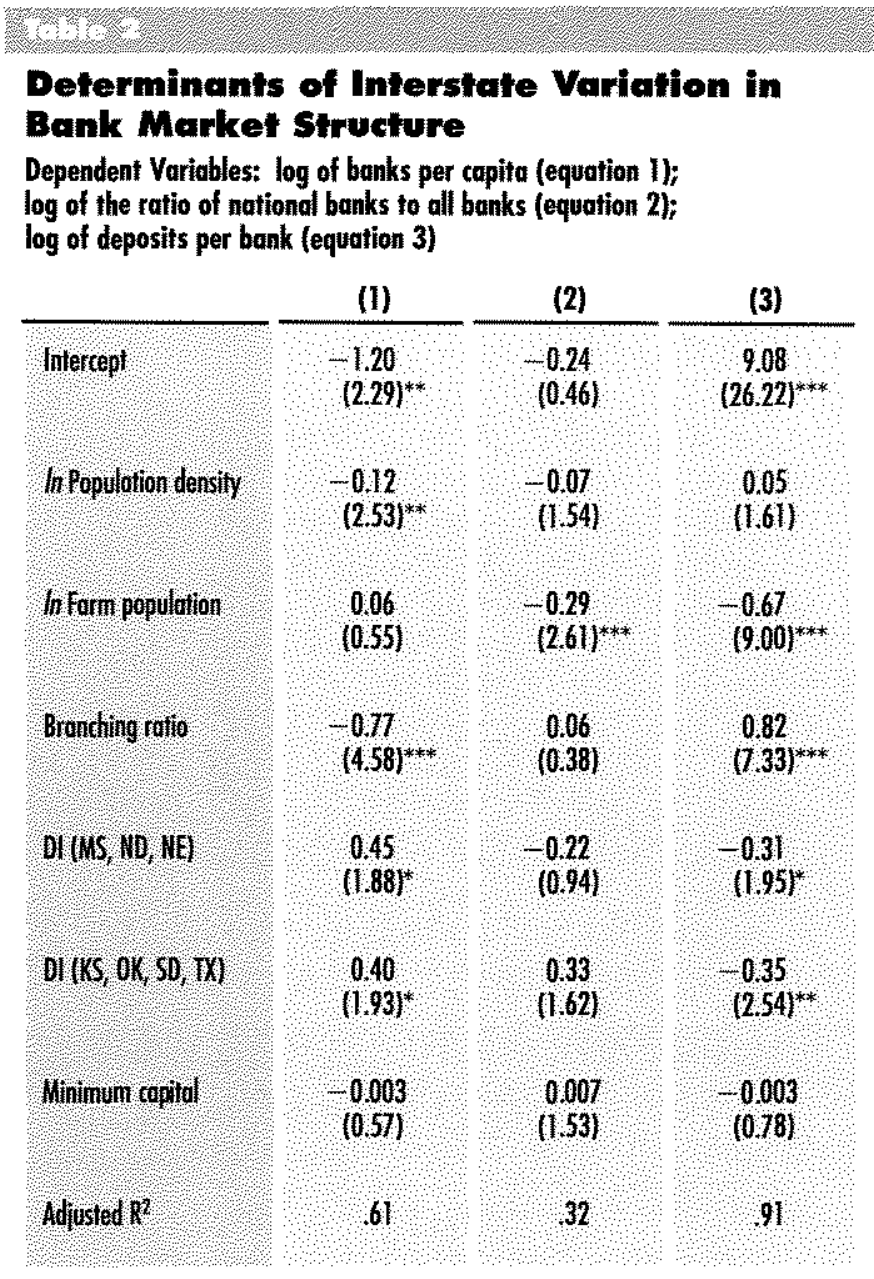

Note: Absolute values of t-statistics are in parentheses; ***, ** and * indicate sfatistical significance ot the $.01,05$ and . 10 levels.

4 The brondiing rotio is positively sorrelated with both the percentutuge Ehothe in per copito income ant business frifure rate. If the latior is omitted, the coefficient on the brenching routo is lorger and statistit catly sigailicant in the benk foilute rate regession. from such models appear to be normally distributed, while those from models of the level of the rate of deposits in failed banks do not. Because the value of this variable for Rhode Island is zero, 1 omitted this observation when estimating the reported regressions. Assigning an arbitrarily small value to this observation and re-estimating the models does not, however, substantially alter the results.

In states with few banks, each bank failure has a larger impact on the failure rate than in states with many banks, which could cause the errors of the model to be larger in states with fewer banks. Hence, to correct for heteroscedasticity, each variable in the failure rate models has been multiplied by the square root of the average annual number of operating banks. Weighting gives more importance to those states, located mainly in the Midwest and South, that had large numbers of banks, and less to states with fewer banks (like those in the West and Northeast).

Models 1 and 5 include only measures of economic activity as independent variables. The more per capita income fell during 1929-32, the higher were both the failure rate and the rate of deposits in failed banks. Typically, states with large declines in per capita income also had relatively high farm failure rates, and the correlation coefficient between these two variables is -0.57 , which is significant at the 0.01 level. Nevertheless, in the bank failure rate model (model 1), the coefficient on the farm failure rate is positive and statistically significant, indicating that a higher farm failure tate caused a higher bank failure rate. The coefficients on the business failure rate, on the other hand, are never statistically different from zero.

Models 2 and 6 include the branch banking ratio and deposit insurance dummy variables as additional regressors. In both models, the coefficient on the branching ratio indicates that bank failure rates were lower where branching was more prevalent, though only in model 6 is the coefficient statistically significant. ${ }^{4}$ This suggests that, where permitted, branching lowered bank failure rates. Perhaps this occurred because branching banks were better diversified, or possibly because branching enabled banks to achieve economies of scale. States with more 
branching tended to have larger banks. The correlation coefficient between the branching ratio and the log of deposits per bank is 0.72 , which is significant at the 0.01 level.

The coefficients on the deposit insurance dummy variables in model 6 are not statistically different from zero. In model 2, however, the dummy for states where insurance ended by the mid-1920s (Kansas, Oklahoma, South Dakota and Texas) has a negative and significant coefficient. In these states, the average annual bank failure rate was some 3 percentage points lower because of deposit insurance. Apparently, deposit insurance affected market structure in a way that reduced failure rates. This might be explained by the comparatively large increase in the relative number of national banks, which had lower failure rates than state banks, in these states. Models 3 and 7 test for this possibility by including the log of the ratio of national banks to total banks as an additional independent variable. Doing so reduces somewhat the absolute size and statistical significance of the deposit insurance coefficient. Insurance appears to have had no effect on the national bank ratio in states where insurance lasted at least until 1928.

The coefficient on deposit insurance for these states is positive and fairly large (though not statistically significant), suggesting that insurance affected bank failure rates in these states by causing excessive numbers of banks or risk-taking.

Models 4 and 8 further indicate how banking market structure affected bank failure rates during the Depression. I exclude branching and deposit insurance from these specifications because their effects on bank failures appear to have worked through their influence on market structure. Further analysis of the determinants of market structure is presented in the next section.

The market structure measures included in models 4 and 8 are the logs of banks per capita in 1929 , the ratio of national to all banks in 1929 , and the average volume of deposits per bank in 1929. Only the coefficients on the ratio of national to all banks is statistically significant. Its negative coefficients indicate that bank failure rates and rates of deposits in failed banks were smaller where national banks were relatively more prevalent. Multi- collinearity might explain the absence of a significant relationship betweer bank size, or the number of banks per capita, and failure rates. The correlation coefficient between the logs of the national bank ratio and average deposits per bank is 0.49 , which is significant at the 0.01 level, while that between the logs of the national bank ratio and number of banks per capita is -0.34 , which is significant at the 0.02 level. The correlation between the national bank ratio and bank size makes it impossible to determine whether differences in regulation or supervision of state and national banks had an impact on failures, except as they might have influenced bank size. The absence of a significant relationship between bank size and failure rates, however, suggests that any influence size had on failures is reflected in the ratio of national banks to all banks.

The inclusion of banks per capita, the national bank ratio and average bank size in the bank failure rate model reduces the statistical significance of the percentage change in per capita income and the farm failure rate. The correlation coefficients between the market structure variables and the two measures of economic activity are all statistically significant at the 1 percent level. The states with the largest declines in per capita income and the highest farm failure rates also had the highest numbers of banks per capita, the lowest national bank ratios and smallest average bank sizes. Although the Depression affected the entire nation, rural farming regions were hit especially hard. Unfortunately, these states also tended to have banking markets consisting of many small, undiversified banks. Thus, it is diffcult, if not impossible, to apportion the comparatively high bank failure rates of these states between changes in the level of economic activity and the vulnerability of their banking systems. ${ }^{5}$ The evidence presented here, however, suggests that banking market structure affected the performance of state banking systems, and adds weight to other research associating banking distress and declining economic activity in the 1930s with banking system fragility (see Bernanke and James, 1991; Calomiris, 1993; and Grossman, 1994).

\footnotetext{
${ }^{5}$ Conceivably, income fell more and faren foiluse rates were higher in these states because their banking imarket stutuctures were more wit nerable to bank foilues. As noted previousty, the meassires of ecro nomic activity ideally would be tredied as dependent variables in a simullaneous-equations franewowk to capture any ingenter of benk toitures on economic activity.
} 
Wha

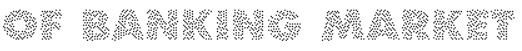

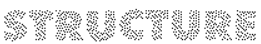

The evidence presented in the preceding section shows that government policies affected bank failure rates during the Depression, at least in part, by causing differences in banking market structure across states. Further insight into the effects of government policies on market outcomes can thus be gleaned from studying interstate variations in banking market structure.

Wheelock (1993) investigates the impact of government policies on banking market structure during the 1920s. There, I show that the number of banks per capita was lower where branch banking was more prevalent, in states that imposed high minimum capital requirements on state-chartered banks, and in states with deposit insurance systems. In addition, the number of banks per capita was lower in more densely populated states. The costs of transportation and communication make the finding of an inverse relationship between population density and the number of banks per capita unsurprising. An inverse relationship between the prevalence of branching and the number of banks per capita is also not surprising. Where permitted, branch offices can serve markets that otherwise would require independent banks. To the extent that branches substitute for unit banks, the number of banks per capita will be lower. Finally, because deposit insurance subsidized entry, and was instituted only in unit banking states, it caused the number of banks per capita to be higher than it would otherwise have been.

Model 1 of Table 2 reports a regression of the log of banks per capita in 1929 on the $\log$ of population density, the branching ratio, the deposit insurance dummy variables, the $\log$ of the ratio of farm to total state population, and the minimum capital requirement imposed on state banks. Only the coefficients on the latter two variables are insignificant.

As expected, the less densely populated a state was, the higher were banks per capita. In addition, in states where there were deposit insurance systems, or where branch banking was less prevalent, banks per capita were again higher.
The same variables are included in a model of the log of the ratio of the number of national banks to total banks. The most important determinant of this ratio is the ratio of farm to total state population: the greater the fraction of the population in agriculture, the lower the relative number of national banks. National banks were more prevalent in Northeastern manufacturing states and other states where agriculture was relatively unimportant. On the one hand, this reflects the lower population density of agricultural states, and that such states often set low minimum capital requirements for their state-chartered banks to ensure the presence of banking facilities in rural areas. Note that the coefficient on the minimum capital ratio is positive and, for a one-tail test, statistically significant at the 0.10 level. State-chartered banks also typically enjoyed fewer lending restrictions than national banks, especially on real estate loans. Consequently, state-chartered banks were able to serve more of the banking needs of agricultural borrowers.

In model 2, the coefficients on the two deposit insurance dummy variables differ significantly from one another. The coefficient on the variable for states where deposit insurance ended early in the 1920 s (Kansas, Oklahoma, South Dakota and Texas) is positive and, for a one-tail test, statistically significant at the 0.10 level. The failure of large numbers of state banks, and the decision of others to switch to national charters, explain why deposit insurance had a positive influence on the national bank ratio in these states. Insurance lasted longer, and generally performed better, in Mississippi, North Dakota and Nebraska and, hence, there was no effect of insurance on the national bank ratio.

Finally, the coefficient on the branching ratio is not statistically different from zero. Until the McFadden Act of 1927 enabled national banks to open branches, virtually all branching was done by state-chartered institutions. The ability to branch might have increased the demand for state charters and, hence, all else equal, had a negative influence on the national bank ratio. On the other hand, it could have also held down state chartering because branch offices substituted for independent state banks. 
Model 3 of Table 2 is a regression of the log of average deposits per bank in 1929. This variable is negatively correlated with the number of banks per capita and positively correlated with the national bank ratio. Hence, the estimates of this model are unsurprising. Banks were larger in more densely populated states and where agriculture was less impor tant. Average bank size was also larger where branching was more prevalent. Apparently, branching enabled banks to achieve larger scale than they otherwise would. Finally, states which had deposit insurance systems tended to have, on average, smaller banks. These were uniformly tural states that prohibited branching. Deposit insurance provided a subsidy that, because of branching restrictions, led to the entry of many small unit banks. The demise of deposit insurance removed this subsidy and, at least in four states, contributed to a shift toward more banks with federal charters. Despite this, the negative impact of insurance on average bank size apparently remained in 1929.

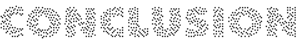

In response to the bank failures of the Great Depression, Congress enacted federal deposit insurance, imposed new restrictions on the activities of commercial banks, and maintained a strict prohibition of interstate branching. Although these policies appeared to work well for many years, their weaknesses were exposed in the 1980s, prompting reforms. Looking back, economic historians have demonstrated the destabilizing effects of deposit insurance and branch banking restrictions in the 1920s. This article illuminates how these policies affected banking market structure and, ultimately, state-level bank failure rates during the Depression. Even though state deposit insurance had ended by 1929 , its effects lingered into the 1930 s, causing both higher numbers of banks per capita and higher ratios of national banks to total banks in states that earlier had insurance systems. At the same time, branching restrictions, where enforced, contributed to the small average size of unit banks and to their higher rate of failure during the Depression. Thus, as others have shown for the 1980s, the geographic distribution of bank failures during the Depression was in part a function of market structure and government banking policies.

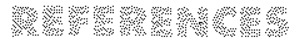

Alston, tee J., Grove, Wayne A. and David C. Wheelock. "Why Do Banks Foil? Evidence from the 1920s," Explorations in Eronomic History (October 1994), pp. 409-31.

Bankers Encylopedio Compony. Polk's Bonkers Encydopedio (March 1929).

Bernonke, Ben S. "Nonmonetory Effects of the Finencial Cises in the Propagation of the Great Lepression," Americon Economic Review (June 1983), pp. 257-76.

and Jomes, Haoud. "The Gold Stondard, Beflotion, and Finuacial Crises in the Great Depression: An Intentationol Comporison," in Hubtord, R. Genn, ed. Financiol Morkets and Financial Crises. Aniversity of Chicogo Press, 1991, ap. 33-68.

Boadd of Governofs of the federal Reserve System. Bonking ond Monetory Stotistics, 1914-41 (1943).

All Bank Stotisfics, 189641955 (1959).

Bremer, C. D. American Bonk Failures. Columbio University Press, 1935.

Colomisis, Charles W. "Finunciol Eacters in the Geent Depressiont," Jound of Econonic Perspectives (spring 1993), pp. 67-86.

"Do 'Yunnerable' Economies Need Deposit Insurence? Lessons from U.S. Agniculture in the 1920s," in Phitip L. Brock, editor, If Texos Were Chile: A Primer on Borking Reform. Institute for Contempoiary Sudies, 1992, po. 237-314.

"Weposit Instrane: Lessons from the Record," Federd Reserve Bonk of Chicego Economic Persoectives (Moy/sune 1989), pp. 10-30.

ond lasenh R. Mason. "Contagion and Bank Failues Duting the Great Depression: The June 1932 Chicago Bonking Panic," working poper, 1994.

Depatment of Agriculture. "The Fam Real Estate Situation, 1930-31," Burewu of Agricultural Economics Circular No. 209 (1931).

"The Form Red Estate Situation, 1932-33," Butens of Agricultural teonomics Chrolor No. 309 (1933).

Deportment of Commerce, Bureau of the Census. Fifteenth Census of the United Sfates, Populafion, vol. I (1931).

wolume N (1932).

Fifteenth Census of the Unifed States, Agriculture, $1932,1933)$

Stafisficol Abstroct of the United States (1930, 1931,

Persand Income By Stofes Since 1929, A Supplement to the Survey of Current Business (1956). 
Federal Deposit Insurance Comoration. Annud Report (1956).

Federal Reserve Board. Bullefin (llecember 1930). (not dated).

"Bonk Suspensions in the United Stotes, 1892-1931,"

Friedmon, Milton, and Anno I. Schwatz. A honetory History of the United States, 1867-1960. Princeton University Press, 1963.

Grossmon, Richaret S. "The Shoe too Dion't Drop: Explaining Bonking Stabitity Dering the Great Depression," Joumol of Economic History (September 1994), pp. 654-82.

Keeley, Michoet C. "Depesit Insurance, Risk, ond Morkes Power in Bonking." Americon frononic Review (December 1990), pp. 1183.200.

Kyzmowski, Lawrence, ond Gordon S. Robents. "Conodian Banking Solvency, 1922-1940," Journal of Maney, Credit and Bonking (August 1993), pp. 361.76.

Stuffer, Robert F. "The Bank Factures of 1930-31," Jounnal of Money, credit ond Bonking (Fobruoty 1981), po. 109-13.

Temin, Peter. Did Monetary Forces Couse the Great Depression? W. W. Noton, 1976.
Tippetts, Chates S. Stote Banks and the Federal Reserve System. D. Won Nostrand Co. 1929.

Wheslock, Dovid C. "Government Policy and Banking Market Stucture in the 1920s," Journol of Fconomic Hisfory (Decenber 1993), gp. $857-79$.

"Oeposit Insuronce and Bank Folures: New Evidence from the 1920s," Economic Inquiry (July 1992), pp. 530-43.

"Monetary Policy in the Great Depsessions: Whot the Fed Did, and Why," this Review (Mherch/April 19921, pp. 3-28.

White, Eugene N. "Before the Glass-Stenghl Ad: An Anolysis of the Investment Bonking Activities of Notionol Bonks," Explorotions in Economic Hisfory (Januoury 1986), pp. $33-55$.

"A Reintempetotion of the Banking Crisis of 1930," Jound of Erononic History (March 1984), pp. 119.38.

Wicker, Elmus. "A Reconsideration of the Couses of the Banking Panic af 1930," Jounnd of Economic History (September 1980), pp. 571.84 .

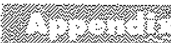

\section{SOURCES FOR STATE-LEVEL DATA}

Bank fallures and deposits in Egiled banks: Boord of Govennors (1943, pp. 284-85).

Branch bonk offices: Federol Reserve Board (December 1930 , 那. 811.12 )

Business failure rofe: Department of Commerce, Statisticol Abstroct $(1930,1931,1932,1933)$

Farm foiture rote: Depomentent of Agrculture $(1931,1933)$.
Farm population: Department of Commerce $(1932$, p. 40).

Minimum copitol fequirement for stote bonks: Bonkers Encydopedio Compony (Morch 1929).

Number of bonks and benk deposits: Board of Governers (1959).

Per copito persontol income: Department of Commerce $(1956, p .142)$.

Population dersity: Deportment of Commerce $(193\}, p, 13)$. 